\title{
Land Use and River Degradation Impact of Sand and Gravel Mining
}

\author{
Putra Rizal Ichsan Syah ${ }^{1, *}$, Purnaweni, Hartuti ${ }^{1,2,3}$ \\ ${ }^{1}$ Master Program of Environmental Science, School of Postgraduate Studies, Diponegoro University, Semarang - Indonesia \\ ${ }^{2}$ Doctorate Program of Environmental Science, School of Postgraduate Studies, Diponegoro University, Semarang - Indonesia \\ ${ }^{3}$ Public Administration Department, Social Science and Political Science, Diponegoro University, Semarang - Indonesia
}

\begin{abstract}
Sand and gravel mining is aimed at providing materials for infrastructure development, as well as providing economical source to the miners. However, the impacts of sand and gravel mining could also cause disturbances to ecological balance, since it is closely related to land use change and river degradation, besides causing conflicts in the miners, the government, and the private relationship. Therefore the government regulation and proper supervision are needed to preserve the ecological balance and decreasing the negative impacts of this mining, and therefore guarantee sustainable development.
\end{abstract}

\section{Introduction}

Man and nature are in essence very much related where humans use nature for their various necessities. At the beginning of the history, the relationship between human and nature is called pan cosmism, in which nature is regarded as something sacred [1]. However, in line with the increasing number of people and much more necessities of these human need to be met, human relationship with nature changed into anthropocentrism. An important feature of anthropocentris is the belief that human beings are not part of nature since they assume themselves have a higher value than nature [2].

A thought that man is able to conquer nature and therefore can do whatever they want is among the main causes that makes the environment is degraded. This is also the case with the uncontrolled use of natural resources which cause serious environmental damage.

This condition is the impact of society's thought that nature can be maximally utilized regardless of the surrounding environment.

Among the badly needs of human beings are taken from natural resources, in the forms of renewable and non renewable resources. Their extraction must be carefully managed, so as not to disturb the existing environmental carrying capacity. Therefore, mining activities must be seriously controlled.

Mining sites are often located in areas with significant biology and environments characteristics, such as in small islands and tropical rainforests [3]. However, these sites are sometimes also located in populated areas, that mining may evoke conflict between the society and the government as a regulator. This also occurred in sand mining activities [4].

In this rapid development era, people have turned to rivers and floodplains as a major source of sand and gravel for construction [5]. Sand and gravel are components of extractable soil, underground geological sources formed from eroding mountain rocks carried by a river. The mining of sand and gravel is one of the activities that positively impact the local economy. Sand and gravel are also important sources for the economic development activities of developed and developing countries [4].

Sand is a very important construction material. UN Environmental Program of Global Environmental Alert Service noted that in concrete processing of infrastructure industry, sand is six to seven times much more consumed than other materials including cement [6]. A very significant prove that sand and gravel are very important for construction materials. However, sand and mining activities also raise various environmental issues both physical and social.

Based on several environmental impacts caused by sand mining activities, this paper will focus on mining and sustainable development, as well as environmental impacts of mining in terms of land use change and river degradation.

\section{Method}

This paper was a result of a library research done through reviews of books and journals tracking, focused on the environmental impacts of sand and gravel mining activities and its relation to sustainable development. This paper was only based on secondary data. The related secondary data were then reviewed to analyze the correlation between sand and gravel mining activities to environmental impacts in terms of changes in land use and river degradation that ultimately impact on the other aspects of environment. It is therefore endanger sustainable development, a paradigm that is a revision of development that was formerly focused mainly on economic benefit into focused on interrelations and interconnection of ecology, ecology and social aspects. 


\section{Environmental Impacts}

Environmental devaluations that result from human activities such as sand/gravel mining on land disturbance ranges from poor or distorted topography, unproductive agricultural terrain, creation of puddles for pest cultivation, deforestation and general degradation of ecosystems with air, ground and land pollution [4].

One of means to meet human needs is through mining which yield various mining materials. However, excessive mining is dangerous as mining significantly change land use and left non reversible impacts, and therefore very potential in damaging the environment. It also increase natural disaster risk, in which the loss could actually exceed the benefit it creates [7].

\subsection{Sustainable Development}

Sustainable development become a popular term in various activities related to human activities. This term was started to be used in the second phase of the 20th century as a reaction to rapid economic growth in many parts of the world, closely related to the intensive use of natural resources. To reduce this phenomenon, in 1972 the World Commission on Environment and Development (WCED) was the first to define sustainable development as development that meets the needs of the present without compromising the ability of future generations to meet their own needs [8].

Keraf in his book entitled Enviromental Ethics explained that the main ideal of sustainable development is an effort to synchronize, integrate, and giving the same weight to three main aspects of development namely economic, social and culture, as well as environment [10]. This is a new paradigm compared to the old, in which development was focused on economic benefit. Development results was weighed on economic calculations such as how much the increase of income per capita, how much of the country's percentage of economic growth. The new paradigm focused not only on economic growth, as when environmental damage was also calculated in the development impacts, the percentage is surely decrease. The Three Pillars of Sustainable Development was stated by Dubinski as follows (see Figure 1)

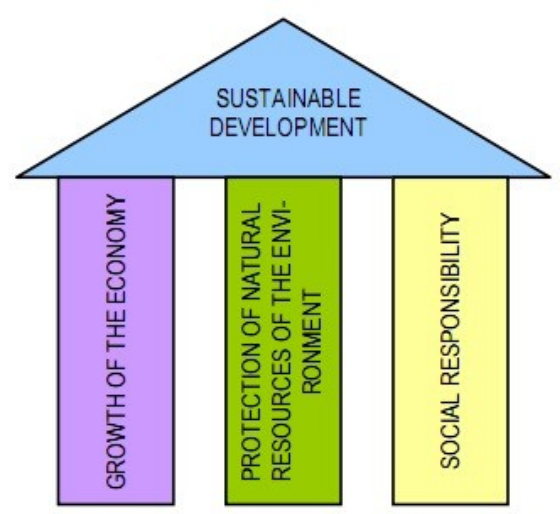

Fig 1. Three Pillars of Sustainable Development in Mining (Dubinski)
The idea behind this new paradigm is that development is a concept in which the system consist of inter related and inter connected sub systems. Each subsystem can not be separated or contradicted to each other. One of the key factors of development success depends on the balance of the three sub systems of sustainable development, as depicted by Dubinski.

The implementation of sustainable development will affect on the sustainability of activities and resources, this also implies to mining activities as shown in Figure 1.

Dubinski stated about three pillars of sustainable development in mining. He said that the intentions behind sustainable development implementation of mineral mining, is as follows : (a) Economy : technical activities that guarantee economic growth ; (b) Ecology : guarantee protection to natural resources and environment; (c) Social Responsibility: meaning the care to the employees both in the work place and in the mining environment [8].

If sustainable development is neglected, the impact will be among others the higher risk or incidents of disaster because of the environmental damage..

In the Law No 32/2009 on Environmental Protection and Management, it is stated that environmental damage is a direct and non-direct change to the physical, chemical, and/ biological resources which exceed standard criteria of environmental damage [10].

Environmental damage is caused by two factors. Keraf stated that among disaster we experience, some of them are pure as natural disasters such as volcanic eruption and earthquake. The rest are environmental disasters as the cause are not pure natural disaster but more impacted from human activities [9]. Hadi is in the same opinion as saying that at an extreme point of the environmental disaster it threatens the continuity of human activities and therefore threatens human existence. An extreme point which must be seriously prevented if human beings are aware of its very existence [11].

Keraf in his book entitled Krisis dan Bencana Lingkungan (Crisis and Environmental Damage) stated that so far the environmental damage are the effects of: (a) fundamental factor or the false in view point; (b) Paradigm false and development policy; (c) Modernization factor; (d) Bad governance; (e)Decentralization and political liberalization; (f) Mutual commitment weakness [12].

Mining activities are very potential to degrading the environment. Sudrajat in his book entitled Teori dan Praktik Pertambangan (Mining Theories and Practice) stated that mining can be regarded as Zero Value activities since there are many impacts of mining based on so many improper technical criteria of good mining governance [13].

\subsection{Land Use Change}

Land basically includes resources both inside and above the surface that can be utilized for human needs. With 
the increase in human needs as the population increases, land use changes will be wider. Conversion of forest land into other land uses is a long-standing phenomenon in the world and has direct impacts such as air pollution, reduced biodiversity, global warming with declining $\mathrm{CO} 2$ binders [14], as well as social impacts [3a/4 AHW]

A research conducted by Musah related to environmental impacts of mining activities in East Gonja District and Gunnarsholt Island, Ghana. Musah revealed that the loss of agricultural and productive land in the Eastern District of Gonja was very significant compared with conditions in Gunnarsholt, in which mining activities at Gunnarsholt are mostly done at highland and barren areas [15]. The effects of mining holes in East Gonja Distrik, Ghana is that the holes became breeding grounds for malaria-causing mosquitoes and other diseases. The results of this study was supported by Kori and Mathada's research at Nzhelele Valley, South Africa that the stagnant water in the excavation pits make a good breeding sites for disease-carrying vectors. Mosquitoes and snails pose a danger of malaria and scistisomiasis to the local communities. They mentioned that the impact of land change from mining can reduce ecological value as well as economic value [4]. The result of this research is almost the same with the research done by Dyahwati in Temanggung, Indonesia that sand mining activity caused the declining of economic value of the land [17].

\subsection{River degradation}

According to Boudaghpour, river gravel and sand are the best known building materials because the dissoluble and frail fragments of the gravel and sand are removed by the water flow and therefore the stable ones remain [18]. Although sand mining is expected to be regulated by law in many places, many are still illegal. It quickly became an ecological problem as demand for sand increased in industry and construction.

However, based on research by Ashraf, et al, mining in the river has a negative impact outside the mine site. Many hectares of fertile land are lost, as well as timber resources and the loss of valuable wildlife habitats. Moreover, degraded river habitats result in loss of fishery productivity, biodiversity and recreation potential [19].

Result of a study done by Devi and Rongmei mining activities in the Imphal River found that excavations along the river had a negative impact on the quality of river water. The impacts of sand mining activities on rivers include short-term turbidity at the excavation site due to sediment reduction, in addition to other environmental impacts such as increased erosion and collapse of riverbanks that increase suspended solids at the excavation sites and downstream rivers [5].

\section{Conclusion}

Sand mining activities carried out in watersheds and around riverbanks have ecological impacts, among others changes in land use that affect the loss of agricultural land and other productive land can cause impact on public health, such as malaria. In addition, sand mining activities in the river can cause river degradation such as sedimentation and erosion, as well as threatening ecosystems in the river water. Sand and gravel mining activities in which main objective is for infrastructure development need proper supervision and good regulation.

Therefore sand and gravel mining endanger sustainable development, which focuses on the sustainability of resources, including natural resources. Therefore, good mining practices which is based on sustainable development must be implemented.

\section{References}

1. R. Dhany. Semarang, (2013) http://dhanyvironment.blogspot.co.id/2013/09/manu sia-kontra-lingkungan.html

2. Beckman, et al. Universidad Carlos 3 de Madrid Journal.

https://portal.uc3m.es/portal/page/portal/grupos_inv estigacion/sociologia_cambio_climatico/Pardo $\% 20$ $\% 20$ Anthropocentrism\%20Environmental\%20Value s\%20(ENG).pdf

3. Devi, Bernadetta and Prayogo, Dody. Mining for Development Centre. AusAID. Australia( 2013)

4. Kori, E and Mathada, H., Environment and Chemistry, IPCBEE, Vol 46, Singapore (2012)

5. Devi, Maharabam Anjali and Rongmei, Lunghim. Asia Pacific Journal of Energy and Environment. Volume 2. Number 2/2015. ABC Research House. (2015)

6. UNEP Global Environment Alert Service (GEAS). Sand, Rarer than one thinks. https://na.unep.net/geas/archive/pdfs/GEAS_Mar20 14_Sand_Mining.pdf. (2014).

7. Purnaweni, H, Policy on Environmental Management in North Kendeng Area, J Ilmu Lingkungan, 12, 1: 53-65, (2014)

8. Dubinsky, J, Sustainable Development of Mining Mineral Resources. J of Sustainable Mining. 12 No. 1: 1-6 (2013).

9. Keraf, S. Etika Lingkungan (Environmental Ethics), Jakarta : Kompas Press, (2002)

10. Law No 32/2009 on Environmental Protection and Management

11. Hadi, SP, Aspek Sosial AMDAL (SEA Social Aspects), Gadjah Mada University Press: Yogyakarta, (2005)

12. Keraf, S, Krisis dan Bencana Lingkungan (Environmental Crisis and Disaster), Kanisius: Yogyakarta, (2010).

13. Sudrajat, Teori dan Praktek Pertambangan (Mining Theory and Practise), Pustaka Yustisia:Yogyakarta, (2013)

14. Hidayat, et al. Journal of Regional and City Planning. 26, No.2, 130-146, Agustus 2015. IPB Repository. Bogor. (2015) (In Bahasa)

15. Musah, Jafaru Adam and Barkarson, Bjorn $\mathrm{H}$. United Nations University Land Restoration 
Training Programme, Agricultural University of Iceland and the Soil Conservation Service of Iceland (2009). http://www.unulrt.is/static/fellows/document/musahj a.pdf

16. Wibowo, AH, The Physical and Social Impacts of Mining Policies on Environents in Bantarbolang Sub-District of Pemalang Regency, Asian Jr. of Microbiol. Biotech. Env Sc, 19, 4:28-33, (2017)

17. Dyahwati, NI, The study of environmental degradation as impact of sand mining in Moutt Sumbing Area (Study Case at Kwadungan Gunung
Village, Kledung District, Temanggung Regency), Theses at Master Program of Environmental Science, Diponegoro University, (2007).

18. Boudaghpour, S. and Monfared, SAH, J. Wseas transaction on Environment and Development. 5, 4, May 2008. (2008). http://www.wseas.us/elibrary/transactions/environm ent/2008/26-102.pdf.

19. Ashraf,et al. Scientific Research and Essays, 6, 6: 1216-1231, (2011). Academic Journals, http://www.academicjournals.org/article/article1380 635625_Ashraf\%20et\%20al.pdf 